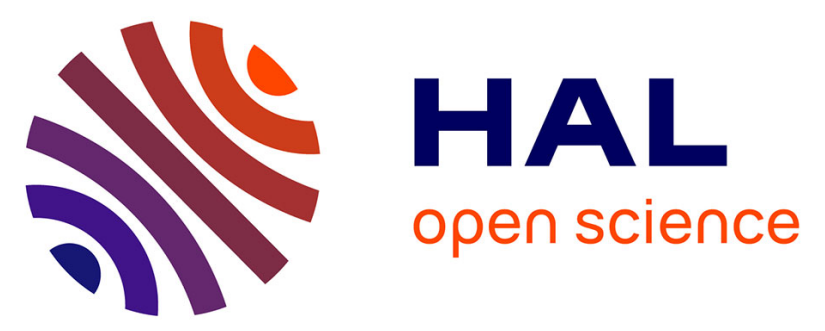

\title{
Understanding of the annealing temperature impact on ion implanted bifacial n-type solar cells to reach $20.3 \%$ efficiency
}

Adeline Lanterne, Jerome Le Perchec, Samuel Gall, Sylvain Manuel, Marianne

Coig, Aurélie Tauzin, Yannick Veschetti

\section{To cite this version:}

Adeline Lanterne, Jerome Le Perchec, Samuel Gall, Sylvain Manuel, Marianne Coig, et al.. Understanding of the annealing temperature impact on ion implanted bifacial n-type solar cells to reach $20.3 \%$ efficiency. Progress in Photovoltaics, 2015, 23 (11), pp.1458-1465. 10.1002/pip.2574 . cea02570664

\section{HAL Id: cea-02570664 https://hal-cea.archives-ouvertes.fr/cea-02570664}

Submitted on 12 May 2020

HAL is a multi-disciplinary open access archive for the deposit and dissemination of scientific research documents, whether they are published or not. The documents may come from teaching and research institutions in France or abroad, or from public or private research centers.
L'archive ouverte pluridisciplinaire HAL, est destinée au dépôt et à la diffusion de documents scientifiques de niveau recherche, publiés ou non, émanant des établissements d'enseignement et de recherche français ou étrangers, des laboratoires publics ou privés. 


\title{
Understanding of the annealing temperature impact on ion implanted bifacial n-type solar cells to reach $\mathbf{2 0 . 3 \%}$ efficiency
}

\author{
Adeline Lanterne $^{1,2 *}$, Jérôme Le Perchec ${ }^{1,2}$, Samuel Gall ${ }^{1,2}$, Sylvain Manuel ${ }^{1,2}$, Marianne Coig $^{3}$, \\ Aurélie Tauzin $^{3}$ and Yannick Veschetti ${ }^{1,2}$ \\ 1 Univ. Grenoble Alpes, INES, F-73375, Le Bourget du Lac, France \\ 2 CEA, LITEN, Department of Solar Technologies, F-73375, Le Bourget du Lac, France \\ 3 CEA, LETI, 17 rue des Martyrs, 38054, Grenoble Cedex 9, France
}

\begin{abstract}
Ion implantation has the advantage of being a unidirectional doping technique. Unlike gaseous diffusion, this characteristic highlights strong possibilities to simplify solar cell process flows. The use of ion implantation doping for n-type PERT bifacial solar cells is a promising process, but mainly if it goes with a unique co-annealing step to activate both dopants and to grow a $\mathrm{SiO}_{2}$ passivation layer. To develop this process and our SONIA cells, we studied the impact of the annealing temperature and that of the passivation layers on the electrical quality of the implanted B-emitter and P-BSF. A high annealing temperature (above $1000^{\circ} \mathrm{C}$ ) was necessary to fully activate the boron atoms and to anneal the implantation damages. Low $\mathrm{J}_{\mathrm{OBSF}}$ (BSF contribution to the saturation current density) of $180 \mathrm{fA} / \mathrm{cm}^{2}$ was reached at this high temperature with the best $\mathrm{SiO}_{2}$ passivation layer. An average efficiency of $19.7 \%$ was reached using this simplified process flow ("co-anneal process") on large area $\left(239 \mathrm{~cm}^{2}\right) \mathrm{Cz}$ solar cells. The efficiency was limited by a low FF, probably due to contaminations by metallization pastes. Improved performances were achieved in the case of a "separated anneals" process where the P-BSF is activated at a lower temperature range. An average efficiency of $20.2 \%$ was obtained in this case, with a $20.3 \%$ certified cell. Copyright (C) 2014 John Wiley \& Sons, Ltd.
\end{abstract}

KEYWORDS

silicon solar cells; ion implantation; n-type; thermal annealing; phosphorus BSF; boron emitter

* Correspondence

Adeline Lanterne, Univ. Grenoble Alpes, INES, F-73375 Le Bourget du Lac, France.

E-mail: Adeline.LANTERNE@cea.fr

Received 26 June 2014; Revised 22 September 2014; Accepted 27 October 2014

\section{INTRODUCTION}

During the last decade, the main objective of the silicon based photovoltaic industry has remained the reduction of the global cost of ownership via the increase of the solar cells efficiency or via the simplification of the fabrication process, which also includes the reduction of consumables and of the breakage rate.

In this context, N-type PERT solar cell has been recently identified as a promising candidate that could replace and exceed the current leadership of the conventional p-type solar cell by reaching both high efficiency and a cost-effective $(\$ / W)$ process [1]. This structure, shown on Figure 1, benefits from all the n-type silicon advantages: the absence of light induced degradation (LID) [2,3], a low sensitivity to metallic impurities and a high lifetime potential [4]. Intrinsically bifacial, this structure has also the potential to achieve an increased energy yield $(\mathrm{kWh} / \mathrm{kWp})$ in module configuration [1]. The main limitation highlighted up to now is the high number of process steps compared to the simple p-type solar cell process. Indeed, using conventional $\mathrm{BBr}_{3}$ and $\mathrm{POCl}_{3}$ high temperature diffusions, several masking steps and chemical oxide removal must be added in order to isolate the front B-emitter from the rear P-BSF [5]. Among the various ways discussed in the literature to simplify this process flow, two solutions have been highlighted: the co-diffusion approach [6] and the use of ion implantation [1,7].

The idea of using ion implantation for the doping of solar cells already appears in the 1980s [8]. But it's only 


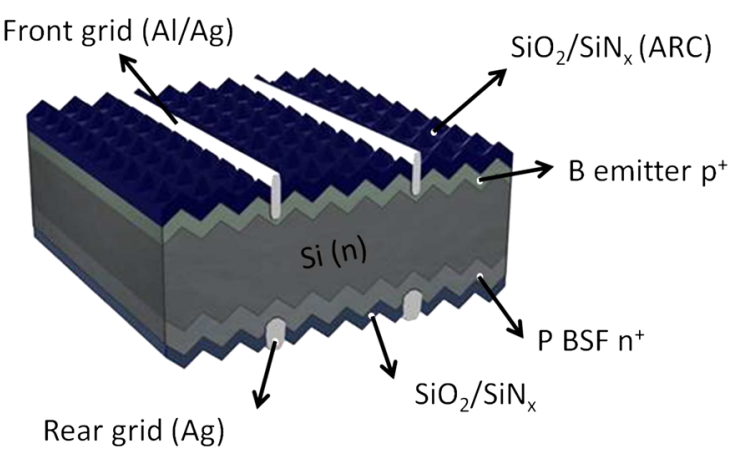

Figure 1. Capture cross section of the n-type PERT solar cell.

recently, thanks to the development of ion implantation tools with higher throughput $[9,10]$, that this technique became compatible with the photovoltaic industry. Since then, its benefits for the fabrication of p-type solar cells have been shown [11]. Unlike diffusion, it has the advantage of precisely controlling the concentration profiles of the junction and of removing the masking and etching steps thanks to its unidirectional doping, but requires an added thermal step to activate the dopants.

In the case of implanted n-type PERT solar cells, the process can be further simplified by the use of a single thermal annealing to activate the front $\mathrm{B}$ and the rear $\mathrm{P}$ implanted atoms. A thermal oxide can also be grown during the dopants activation annealing, leading to a high passivation quality layer without additional step. However, the main challenge remains the realization of a high quality implanted boron emitter, which needs the use of high annealing temperatures [12].

The best efficiencies reported so far on implanted ntype PERT solar cells with screen-printing metallization grids have reached $20.5 \%$ using $\mathrm{Al}_{2} \mathrm{O}_{3}$ boron passivation [13]. The $\mathrm{SiO}_{2}$ passivation has also been investigated in several publications, but efficiencies in this case have been limited below $20 \%$ due to lower $\mathrm{V}_{\mathrm{oc}}$ and $\mathrm{J}_{\mathrm{sc}}[14,15]$. However, $Y$. Tao in [15] managed to increase the $V_{\text {oc }}$ thanks to a planar rear surface and a lower metal coverage (point contacts). Compared to $\mathrm{Al}_{2} \mathrm{O}_{3}$ passivation, $\mathrm{SiO}_{2}$ can bring a significant advantage for industrialization in the case of a concomitant growth during the activation annealing. Therefore we focused our study on this latter passivation technique, using a grid screen-printing on the rear side and no point contacts to keep the bifacial cell advantages.

Our main goal was to develop the simplest process as possible, which involves the use of a "co-anneal" step for $\mathrm{B}$ and $\mathrm{P}$ dopant activation as well as $\mathrm{SiO}_{2}$-based passivation. For this purpose, we first studied the quality of the B-implanted emitter and P-implanted BSF depending on the annealing temperature and passivation stacks. Symmetrical $\mathrm{p}^{+} / \mathrm{n} / \mathrm{p}^{+}$and $\mathrm{n}^{+} / \mathrm{n} / \mathrm{n}^{+}$structures were used for this study. Complete solar cells were then fabricated with the "co-anneal" process. For a better understanding of the limitations of this process, they were compared to solar cells fabricated using a "separated anneals" approach, where a second anneal is added to activate the $\mathrm{P}$ dopants at a lower temperature. The resulting components are called SONIA cells (Solar N-type Implanted Advanced cells).

\section{EXPERIMENT}

Czochralski (Cz) n-type wafers of $3.5 \Omega . \mathrm{cm}\left(239 \mathrm{~cm}^{2}\right)$ were used for symmetrical samples studies as well as for solar cells fabrication.

\subsection{Symetrical $p^{+} n p^{+}$and $n^{+} n n^{+}$samples}

Symmetrical $\mathrm{p}^{+} / \mathrm{n} / \mathrm{p}^{+}$samples were fabricated to measure the B-emitter quality. The influence of the annealing temperature and of the boron implantation dose was studied in the optimal conditions. This involves the use of polished wafers with an $\mathrm{Al}_{2} \mathrm{O}_{3}$ layer deposition for the emitter passivation. The overall process flow is detailed on Figure 2 (" $\mathrm{Al}_{2} \mathrm{O}_{3}$ process"), only the $\mathrm{KOH}$ texture is removed. The wafers were implanted with boron using a beamline implanter with doses ranging from $1.10^{14}$ to $8.10^{14}$ at/ $\mathrm{cm}^{2}$. The boron atoms were activated by two different thermal anneals in nitrogen $\left(\mathrm{N}_{2}\right)$ ambient, the former with a peak temperature $\mathrm{T}_{\mathrm{p}}$ of $950{ }^{\circ} \mathrm{C}$ and the latter with a $\mathrm{T}_{\mathrm{p}}$ of $1050{ }^{\circ} \mathrm{C}$.

The influence of the passivation layer on the emitter quality was also studied. For this study, symmetrical $\mathrm{p}^{+} / \mathrm{n} / \mathrm{p}^{+}$samples were fabricated in the same conditions than the solar cells processing, meaning that the wafers were textured $(\mathrm{KOH} 1 \%)$ at the beginning of the process. Three different passivation stacks were compared on the boron emitter for a fixed implantation dose and a thermal annealing at $\mathrm{T}_{\mathrm{p}}=1050{ }^{\circ} \mathrm{C}$ (corresponding to an emitter sheet resistance $\left(\mathrm{R}_{\text {sheet }}\right)$ of $\left.90 \Omega / \mathrm{sq}\right)$. The formation of the three passivation stacks (named " $\mathrm{Al}_{2} \mathrm{O}_{3}$ ", "etched- $\mathrm{Al}_{2} \mathrm{O}_{3}$ " and " $\mathrm{SiO}_{2}$ ") is detailed on Figure 2. In the "etched- $\mathrm{Al}_{2} \mathrm{O}_{3}$ " case, an oxidation step was included during the annealing of boron, and the resulting grown $\mathrm{SiO}_{2}$ layer was then removed by a $\mathrm{HF}$ dip before $\mathrm{Al}_{2} \mathrm{O}_{3}$ deposition.

Finally, $\mathrm{n}^{+} / \mathrm{n} / \mathrm{n}^{+}$samples were fabricated by a similar process flow, to study the impact of the annealing

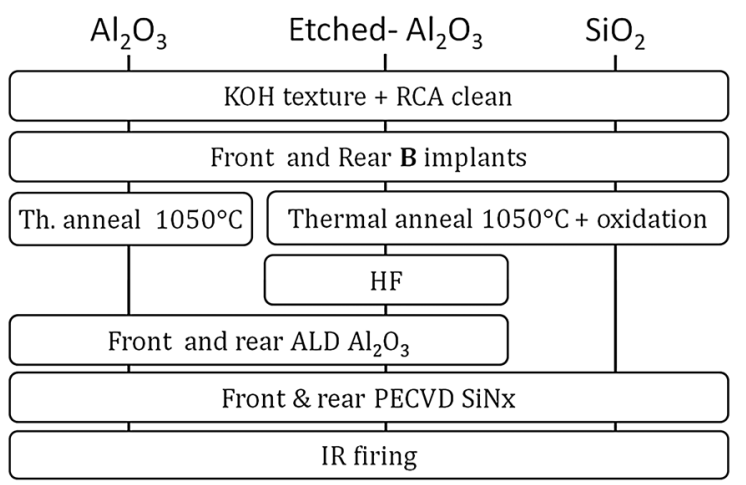

Figure 2. Symmetrical $\mathrm{p}^{+} / \mathrm{n} / \mathrm{p}^{+}$sample process flows depending on the passivation layers. 
temperature on the P-BSF electrical quality. Following the P-implantation on textured wafers, thermal anneals of $1 \mathrm{~h}$ were used for $\mathrm{P}$ activation with peak temperatures ranging from $850{ }^{\circ} \mathrm{C}$ to $1050{ }^{\circ} \mathrm{C}$. Two different $\mathrm{SiO}_{2} / \mathrm{SiN}_{\mathrm{x}}$ stacks were compared for the passivation (stack A and stack B). $\mathrm{A}$ and $\mathrm{B}$ differ in the thicknesses of $\mathrm{SiO}_{2}$ and $\mathrm{SiN}_{\mathrm{x}}$ layers. $\mathrm{The} \mathrm{SiO}_{2}$ thickness is larger in stack $\mathrm{A}$ along with a thinner $\mathrm{SiN}_{\mathrm{x}}$ layer.

An annealing in an infra-red belt-furnace was performed on all the symmetrical samples, before the characterization, to simulate the co-firing cycle of the screen-printed pastes. Samples were then characterized by the QSSPC technique developed by Sinton Consulting [16] to extract the saturation current density of the emitter $\left(\mathrm{J}_{0 \mathrm{e}}\right)$, the saturation current density of the $\mathrm{BSF}\left(\mathrm{J}_{\mathrm{OBSF}}\right.$ or $\left.\mathrm{J}_{0 \mathrm{~b}^{\prime}}\right)$ and their corresponding implied $\mathrm{V}_{\mathrm{oc}}$. The $\mathrm{R}_{\text {sheet }}$ was measured on these samples by four-point probe method. For an accurate measurement of the sheet resistance $\left(\mathrm{R}_{\text {sheet }}\right)$ of the P-BSF, the same process was performed on p-type wafers for each annealing temperature.

\subsection{Solar cell fabrication}

The two process flows, presented on Figure 3, were used for the fabrication of the SONIA cells.

Both processes started by a $\mathrm{KOH}$ texture and a RCA clean. In the process named "co-anneal" the RCA clean was followed by the B implantation on the front side and by the $\mathrm{P}$ implantation on the rear side. Both dopants were then activated by a thermal anneal at $\mathrm{T}_{\mathrm{p}}=1050^{\circ} \mathrm{C}$ with an annealing scheme called "Anneal HT". In the "separated anneals" process, the RCA clean was followed by the $\mathrm{B}$ implantation on the front side and its activation under the "Anneal HT" at $1050{ }^{\circ} \mathrm{C}$. Next, P ions were implanted on the backside, and a second anneal with a lower temperature range $\left(\mathrm{T}_{\mathrm{p}}<900{ }^{\circ} \mathrm{C}\right)$ was used for the $\mathrm{P}$ activation ("Anneal LT"). The front and rear side of the cells were then passivated by $\mathrm{SiO}_{2} / \mathrm{SiN}_{\mathrm{x}}$ stacks. The stack A was used on the "co-anneal" $\mathrm{BSF}\left(\mathrm{BSF}_{\mathrm{A}}\right)$ and the stack $\mathrm{B}$ on the "separated anneals" BSF $\left(\mathrm{BSF}_{\mathrm{B}}\right)$. Explanation for this

\begin{tabular}{|c|c|}
\hline Co-anneal & Separated anneals \\
\hline $\mathrm{KOH}$ texture + clean & $\mathrm{KOH}$ texture + clean \\
\hline Front B implant & Front B implant \\
\hline Rear P implant & Anneal HT \\
\hline Anneal HT & Rear $\mathbf{P}$ implant \\
\hline Front \& rear $\mathrm{SiO} 2 / \mathrm{SiNx}$ & Anneal LT \\
\hline Front \& rear & Front \& rear $\mathrm{SiO} 2 / \mathrm{SiNx}$ \\
\hline \multirow[t]{2}{*}{ Contact firing } & $\begin{array}{c}\text { Front \& rear } \\
\text { screen-printing grid }\end{array}$ \\
\hline & Contact firing \\
\hline
\end{tabular}

Figure 3. Implanted n-type PERT process flows. choice will be provided in the following section. The end of the fabrication was similar for both processes. Contacts were ensured by the screen-printing of grids using $\mathrm{Al} / \mathrm{Ag}$ and Ag pastes on the front and rear side, respectively, with a co-firing in an infra-red (IR) belt-furnace.

Illuminated I-V (AM1.5) and Dark I-V characteristics were measured at $25^{\circ} \mathrm{C}$ on a reflective gold plated chuck.

\section{RESULTS AND DISCUSSION}

\subsection{Impact of the annealing temperature and $\mathrm{SiO}_{2}$ passivation on the B-emitter}

The main challenge of the implanted n-type PERT process is the activation of implanted boron atoms. It has been widely demonstrated this last year, that depending on the boron implantation dose, temperatures above $950{ }^{\circ} \mathrm{C}$ are necessary, to fully activate the implanted boron atoms and cured the implantation damages [12].

The impact of the annealing temperature on the emitter quality was studied for various implantation doses using the optimal conditions (polished wafers and $\mathrm{Al}_{2} \mathrm{O}_{3}$ ALD deposition).

Figure 4 a) shows the $\mathrm{R}_{\text {sheet }}$ measured on $\mathrm{SiN}_{\mathrm{x}} / \mathrm{Al}_{2} \mathrm{O}_{3} /$ $\mathrm{p}^{+} / \mathrm{n} / \mathrm{p}^{+} / \mathrm{Al}_{2} \mathrm{O}_{3} / \mathrm{SiN}_{\mathrm{x}}$ samples. For both annealing peak temperatures $\left(\mathrm{T}_{\mathrm{p}}=950^{\circ} \mathrm{C}\right.$ and $\left.\mathrm{T}_{\mathrm{p}}=1050^{\circ} \mathrm{C}\right)$, the $\mathrm{R}_{\text {sheet }}$ values exhibit a strong decrease for an increasing implantation dose, down to $150 \Omega / \mathrm{sq}$ for $8 \times 10^{14}$ at. $\mathrm{cm}^{-2}$. This trend is explained by an increase of the active boron concentration due to the higher implantation dose as it can be seen on Figure 5 which presents the active boron concentration profiles measured by electrochemical capacitance-voltage analysis (ECV). The differences of $\mathrm{R}_{\text {sheet }}$ between both annealing temperatures, observed for the lowest implantation doses, were explained by the change in the carrier mobility due to the difference in the boron concentration profile between a $950^{\circ} \mathrm{C}$ and a $1050{ }^{\circ} \mathrm{C}$ annealing [17].

Figure $4 \mathrm{~b}$ ) shows the $\mathrm{J}_{0 \mathrm{e}}$ values measured on the same samples. For the lowest dose $\left(1 \times 10^{14}\right.$ at. $\left.^{-3}\right)$, very low $\mathrm{J}_{0 \mathrm{e}}$ values (under $20 \mathrm{fA} . \mathrm{cm}^{-2}$ ) were measured for both annealing temperatures. These low $\mathrm{J}_{0 \mathrm{e}}$ values reveal a complete activation of the boron implanted atoms and the annealing of all the implantation damages. In the case of a higher implantation dose, corresponding to $\mathrm{R}_{\text {sheet }}$ closer to $100 \Omega /$ sq, only the highest annealing temperature allows us to reach a low $\mathrm{J}_{0 \mathrm{e}}$ value. These results are in agreement with previous studies [12] and confirm that for the formation of a boron emitter suitable for contact by screenprinting metallization $\left(\mathrm{R}_{\text {sheet }}\right.$ below $\left.150 \Omega / \mathrm{sq}\right)$, a $1050{ }^{\circ} \mathrm{C}$ peak temperature is highly recommended to reach a high emitter electrical quality.

The $1050{ }^{\circ} \mathrm{C}$ peak temperature was kept in the following studies to form a $90 \Omega /$ sq boron emitter, thanks to implantation dose optimisations between $8 \times 10^{14} \mathrm{at} / \mathrm{cm}^{2}$ and $3 \times 10^{15} \mathrm{at} / \mathrm{cm}^{2}$. To estimate the loss due to the use of a $\mathrm{SiO}_{2}$ layer instead of an $\mathrm{Al}_{2} \mathrm{O}_{3}$ based passivation, mainly 

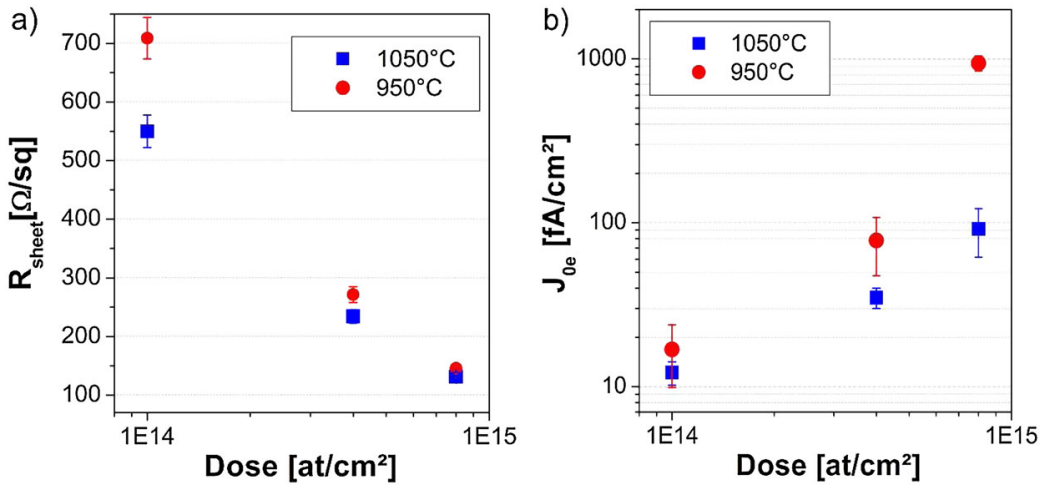

Figure 4. a) $R_{\text {sheet }}$ and b) $J_{0 e}$ measured on implanted $\mathrm{SiN}_{x} / \mathrm{Al}_{2} \mathrm{O}_{3} / \mathrm{p}^{+} / \mathrm{n} / \mathrm{p}^{+} / \mathrm{Al}_{2} \mathrm{O}_{3} / \mathrm{SiN}_{\mathrm{x}}$ samples annealed at $\mathrm{T}_{\mathrm{p}}=950^{\circ} \mathrm{C}$ or $\mathrm{T}_{\mathrm{p}}=1050^{\circ} \mathrm{C}$.

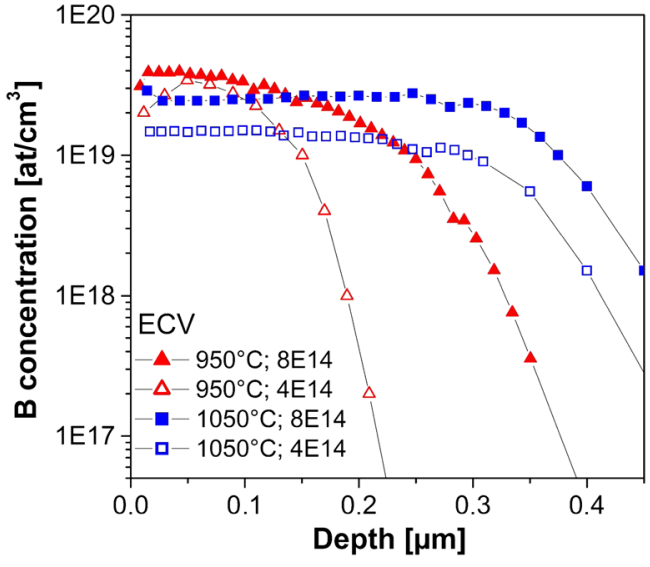

Figure 5. ECV profiles of boron implanted emitters with implantation dose of $8 \times 10^{14} \mathrm{at} / \mathrm{cm}^{2}$ or $4 \times 10^{14} \mathrm{at} / \mathrm{cm}^{2}$ annealed at $\mathrm{T}_{\mathrm{p}}=950^{\circ} \mathrm{C}$ or $\mathrm{T}_{\mathrm{p}}=1050^{\circ} \mathrm{C}$.

used in literature, we compared the $\mathrm{R}_{\text {sheet }}$, implied $\mathrm{V}_{\mathrm{oc}}$ and $\mathrm{J}_{0 \mathrm{e}}$ values obtained on $\mathrm{p}^{+} / \mathrm{n} / \mathrm{p}^{+}$textured samples.

Results for three different passivation stacks are shown on Figure 6 including $\mathrm{Al}_{2} \mathrm{O}_{3} / \mathrm{SiN}_{\mathrm{x}}$ layers deposited after the boron activation or after an emitter etching. Implied $\mathrm{V}_{\mathrm{oc}}$ and $\mathrm{J}_{0 \mathrm{e}}$ are improved with an etching step previous to the $\mathrm{Al}_{2} \mathrm{O}_{3}$ deposition. This was explained by the removal of the damage surface along with a small increase of the emitter sheet resistance. These advantages are also present in the case of the $\mathrm{SiO}_{2}$ passivation but are not sufficient to reach similar implied $\mathrm{V}_{\mathrm{oc}}$ values than with the $\mathrm{Al}_{2} \mathrm{O}_{3}$ layers. An average loss of $6 \mathrm{mV}$ was measured on the implied $\mathrm{V}_{\mathrm{oc}}$ by using $\mathrm{SiO}_{2}$ passivation corresponding to a $\mathrm{J}_{0 \mathrm{e}}$ value of $131 \mathrm{fA} / \mathrm{cm}^{2}$.

\subsection{Impact of the annealing temperature on the P-BSF}

Previous results have shown that for high implantation dose a peak temperature of $1050{ }^{\circ} \mathrm{C}$ is needed to activate the boron emitter during solar cell fabrication. Therefore this temperature must also be used for the P-BSF activation in the case of a "co-anneal" process flow. The impact of this high annealing temperature on the P-BSF quality was studied in the following section.

Figure 7 shows the sheet resistance measured on textured p-type $\mathrm{n}^{+} / \mathrm{p} / \mathrm{n}^{+}$phosphorus implanted samples annealed during 1 hour at various temperatures. For a given dose, the $\mathrm{R}_{\text {sheet }}$ decreases with increasing annealing temperature from $63 \Omega / \mathrm{sq}$ at $850^{\circ} \mathrm{C}$ to $33 \Omega / \mathrm{sq}$ at $1050{ }^{\circ} \mathrm{C}$.
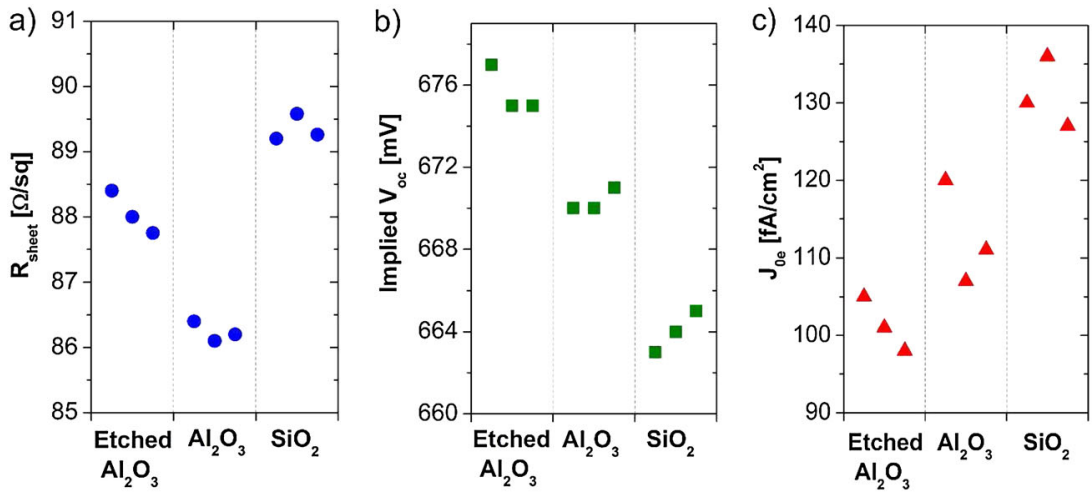

Figure 6. a) $R_{\text {sheet, }}$ b) implied $V_{o c}$ and c) $J_{0 e}$ measured on boron implanted emitter annealed at $T_{p}=1050{ }^{\circ} \mathrm{C}$ with various passivation stacks. 
This trend was attributed to a change in the $\mathrm{P}$ concentration profile, which shows a reduced surface doping and increased depth at higher annealing temperatures (cf. Figure 8). Indeed,

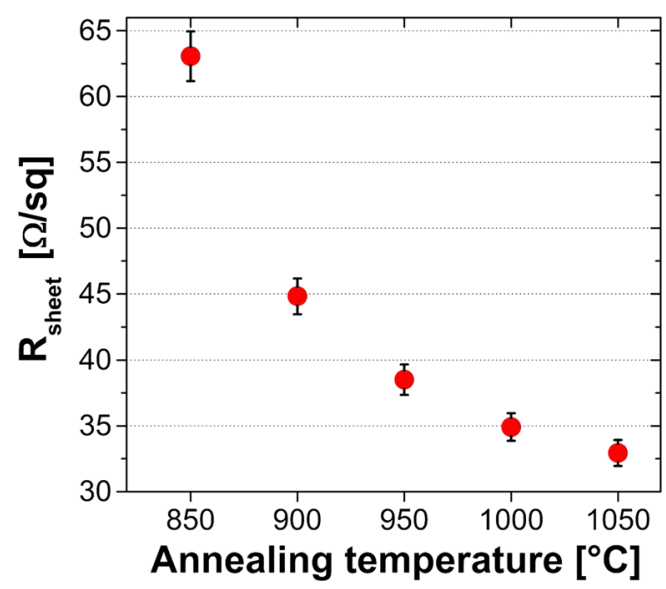

Figure 7. $\mathrm{R}_{\text {sheet }}$ of implanted phosphorus BSF annealed at various temperatures during $1 \mathrm{~h}$.

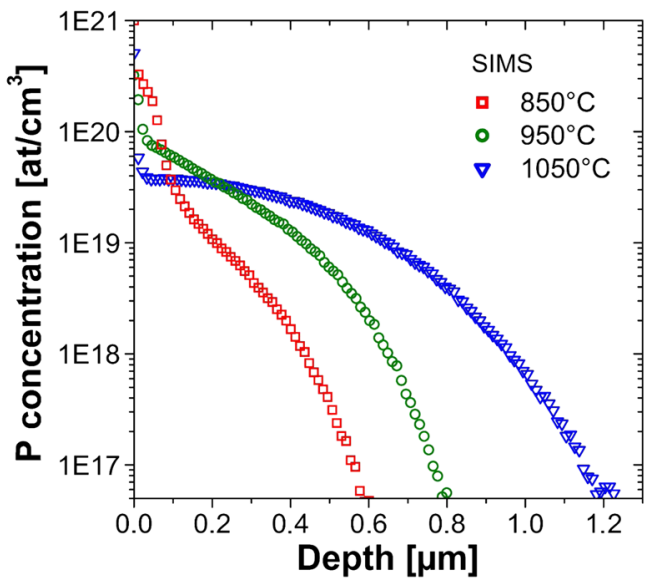

Figure 8. SIMS measurements in the Si of the phosphorus implanted BSF annealed at various temperatures during $1 \mathrm{~h}$ followed by an oxidation step.

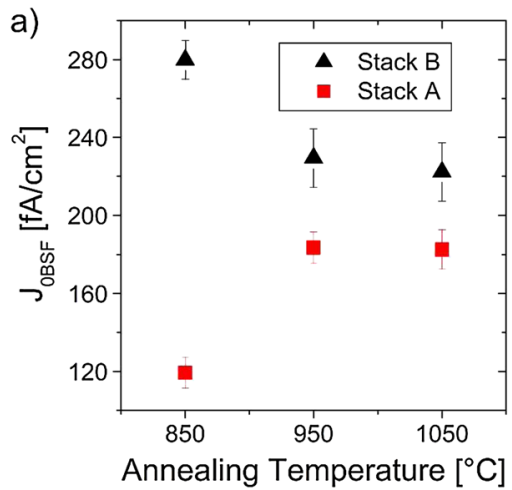

as it was highlighted in our previous work on p-type silicon solar cells, all the phosphorus atoms are already activated at $850^{\circ} \mathrm{C}$ [18]. Therefore the $\mathrm{R}_{\text {sheet }}$ decrease is only due to an increase of the carrier mobility for lower concentrated profiles [17].

Figure 9 shows the $\mathrm{J}_{\mathrm{OBSF}}$ and the implied $\mathrm{V}_{\mathrm{oc}}$ measured on $\mathrm{SiN}_{\mathrm{x}} / \mathrm{SiO}_{2} / \mathrm{n}^{+} / \mathrm{n} / \mathrm{n}^{+} / \mathrm{SiO}_{2} / \mathrm{SiN}_{\mathrm{x}}$ samples using two different $\mathrm{SiO}_{2} / \mathrm{SiN}_{\mathrm{x}}$ stacks. For all the conditions, the $\mathrm{J}_{0 \mathrm{BSF}}$ values are below $300 \mathrm{fA} / \mathrm{cm}^{2}$, which confirms a high activation rate of the $\mathrm{P}$ implanted atoms. An improvement of both parameters is obtained with the stack A (thicker $\mathrm{SiO}_{2}$ layer) for each annealing temperature leading to $\mathrm{J}_{0 \mathrm{BSF}}$ below $200 \mathrm{fA} / \mathrm{cm}^{2}$. An additional benefit is measured at $850^{\circ} \mathrm{C}$ with the stack $\mathrm{A}$, where the implied $\mathrm{V}_{\mathrm{oc}}$ exceeds $670 \mathrm{mV}$.

SIMS measurements, shown on Figure 10, highlight the variation of the phosphorus concentration profile depending on the passivation stack at $850^{\circ} \mathrm{C}$. In the case of stack A, a large part of the emitter was consumed during the $\mathrm{SiO}_{2}$ grow leading to a lightly doped emitter of $120 \Omega / \mathrm{sq}$.

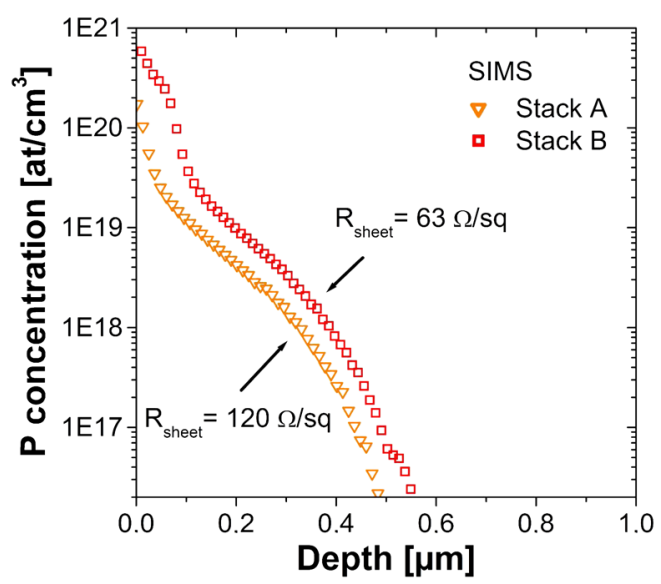

Figure 10. SIMS profiles measured in the Si after $\mathrm{P}$ implantation, annealing during $1 \mathrm{~h}$ at $850^{\circ} \mathrm{C}$ and passivation by stack $\mathrm{A}$ or $\mathrm{B}$.

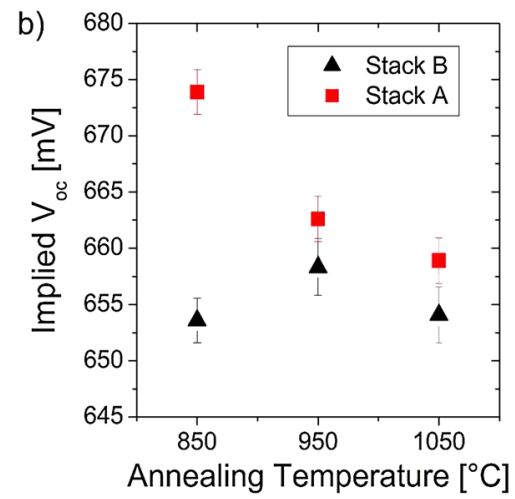

Figure 9. a) $\mathrm{J}_{\mathrm{OBSF}}$ and b) implied $\mathrm{V}_{\mathrm{OC}}$ measured on $\mathrm{P}$ implanted $\mathrm{SiN}_{\times} / \mathrm{SiO}_{2} / \mathrm{n}^{+} / \mathrm{n} / \mathrm{n}^{+} / \mathrm{SiO}_{2} / \mathrm{SiN}_{\times}$samples annealed during $1 \mathrm{~h}$ at various temperatures. 
Table I. Variation of the BSF $\mathrm{R}_{\text {sheet }}$ and of the contact resistivity on the P-BSF depending on the annealing temperature and passivation stack

\begin{tabular}{llrc}
\hline Anneal & Passivation & $R_{\text {sheet }}[\Omega / s q]$ & $\rho_{\text {contact BSF }}\left[\mathrm{m} \Omega . \mathrm{cm}^{2}\right]$ \\
\hline $850^{\circ} \mathrm{C}$ & Stack B & $63 \pm 1$ & $5 \pm 2$ \\
& Stack A & $120 \pm 4$ & $25 \pm 5$ \\
$950^{\circ} \mathrm{C}$ & Stack B & $38 \pm 1$ & $5 \pm 2$ \\
& Stack A & $41 \pm 1$ & $4 \pm 2$ \\
\hline
\end{tabular}

This explains the strong improvement of the $\mathrm{J}_{0 \mathrm{BSF}}$ and of the Implied $\mathrm{V}_{\mathrm{oc}}$ measured in this case (cf. Figure 9).

$\mathrm{Al} / \mathrm{Ag}$ based metallization pastes were screen-printed on the implanted P-BSF annealed at $850{ }^{\circ} \mathrm{C}$ and $950{ }^{\circ} \mathrm{C}$ and passivated by stacks $\mathrm{A}$ and $\mathrm{B}$. After an IR-firing step in a belt-furnace, the contact resistivity was measured by the Berger method on these samples [19]. Results are shown on Table I along with the sheet resistance measured on each BSF. $\mathrm{R}_{\text {sheet }}$ and $\rho_{\text {contact BSF }}$ are similar for each passivation stack at $950^{\circ} \mathrm{C}$ while a strong increase of both parameters is observed at $850^{\circ} \mathrm{C}$ in the case of stack $\mathrm{A}$.

Due to the difficulties to contact the P-BSF with the stack A at low annealing temperature, stack A was kept for solar cell fabrication only in the "co-anneal" approach where the phosphorus is activated at $\mathrm{T}_{\mathrm{p}}=1050^{\circ} \mathrm{C}$. Despite its lower quality, stack B was integrated in the "separated anneals" solar cells where the annealing peak temperature is lower $\left(\mathrm{T}_{\mathrm{p}}<900^{\circ} \mathrm{C}\right)$. The resulting $\mathrm{BSF}$, named $\mathrm{BSF}_{\mathrm{B}}$, corresponds to a more concentrated and thinner BSF than the $\mathrm{BSF}_{\mathrm{A}}$ formed in the co-annealed approach (see Figure 8).

\subsection{N-type PERT implanted solar cells results}

Table II shows the Illuminated I-V parameters measured on solar cells fabricated by both "separated anneals" and "co-anneal" processes with batches of 15 cells. Based on symmetrically textured $\mathrm{Cz} 156 \mathrm{~mm}$ wafers, they were measured on a reflective gold plated chuck and calibrated with a solar cell certified by Fraunhofer ISE CalLab. An average efficiency of $19.7 \%$ was measured with the "co-anneal" approach, and an average efficiency of $20.2 \%$ in the "separated anneals" case. These results demonstrate the possibility to exceed an efficiency of $20 \%$ and a $\mathrm{V}_{\mathrm{oc}}$ of $650 \mathrm{mV}$ by using $\mathrm{SiO}_{2}$ passivation and conventional screen-printing grids on bifacial n-type PERT cells. Similar $\mathrm{V}_{\mathrm{oc}}$ and uniform $\mathrm{J}_{\mathrm{sc}}$ of $39.1 \mathrm{~mA} / \mathrm{cm}^{2}$ were measured for both processes. The main difference remains in the value of the FF, which is lower in the case of the "co-anneal".

Table II. Average I(V) performances of implanted n-type PERT solar cells.

\begin{tabular}{lccccc}
\hline Cell type & $i V_{o c}[\mathrm{mV}]$ & $V_{o c}[\mathrm{mV}]$ & $J_{s c}\left[\mathrm{~mA} . \mathrm{cm}^{2}\right]$ & $F F \%]$ & $\eta[\%]$ \\
\hline Separated anneals & 667 & 651.5 & 39.1 & 79.1 & 20.2 \\
Co-anneal & 671 & 650.6 & 39.1 & 77.3 & 19.7 \\
\hline
\end{tabular}

Implied $\mathrm{V}_{\mathrm{oc}}\left(\mathrm{iV}_{\mathrm{oc}}\right)$, measured before screen-printing steps, exhibit a higher potential for the co-anneal process (cf. Table II). This is in agreement with results obtained on $\mathrm{n}^{+} / \mathrm{n} / \mathrm{n}^{+}$samples where a higher BSF quality was measured at $1050{ }^{\circ} \mathrm{C}$ using the passivation stack A than at lower temperature with stack B. However after metallization the drop of $\mathrm{V}_{\mathrm{oc}}$ is slightly stronger in the case of the co-anneal process, resulting in similar $\mathrm{V}_{\mathrm{oc}}$ values for both processes.

Spectral responses were performed on both types of solar cells to measure the external quantum efficiency (EQE). The EQE curves and the reflectivity were both measured between the metallization grids (cf. Figure 11). For a better clarity, only the reflectivity of the "co-annealed" process is shown in Figure 11 as the curves were identical for both processes. Despite the difference in the BSF annealing temperature and in the passivation stack, the two different cells resulted in similar EQE curves with the same response for both $\mathrm{BSF}\left(\mathrm{BSF}_{\mathrm{A}}\right.$ and $\left.\mathrm{BSF}_{\mathrm{B}}\right)$.

Further characterizations were made to understand the FF gap between the two processes. Dark I-V curves were measured in order to extract the dark shunt resistance $\left(\mathrm{R}_{\text {shunt }}\right)$. Suns- $\mathrm{V}_{\mathrm{oc}}$ measures were also made to determine the PFF of the solar cell as well as the saturation current density of the second diode $\left(\mathrm{J}_{02}\right)$ and the series resistance. Series resistances $\left(\mathrm{R}_{\mathrm{s}}\right)$ were calculated by comparing the Suns- $\mathrm{V}_{\text {oc }}$ and the illuminated $\mathrm{I}-\mathrm{V}$ curve as described by D. Pysch in [20]. Finally the contact resistivity was measured by the Berger method on both BSF [19]. Results of these measurements are summarized in Table III.

On one hand, a higher series resistance was measured on the "co-anneal" cells. This was explained by a higher contact resistivity on the $\mathrm{BSF}_{\mathrm{A}}$ than on the $\mathrm{BSF}_{\mathrm{B}}$. On the other hand, the PFF shows a drop for the "co-anneal" case similar to the drop of the FF and so seems to be the main parameter that drives the FF. It is well known that the PFF can be limited by both the $\mathrm{R}_{\text {shunt }}$ and the $\mathrm{J}_{02}$ value. The $R_{\text {shunt }}$ shows a similar value for both processes but $\mathrm{J}_{02}$ is one order of magnitude higher in the "co-anneal" case. In conclusion, the main limitation of the "co-anneal" solar cells, with its deep phosphorus BSF, is an especially low PFF due to a deteriorated $\mathrm{J}_{02}$.

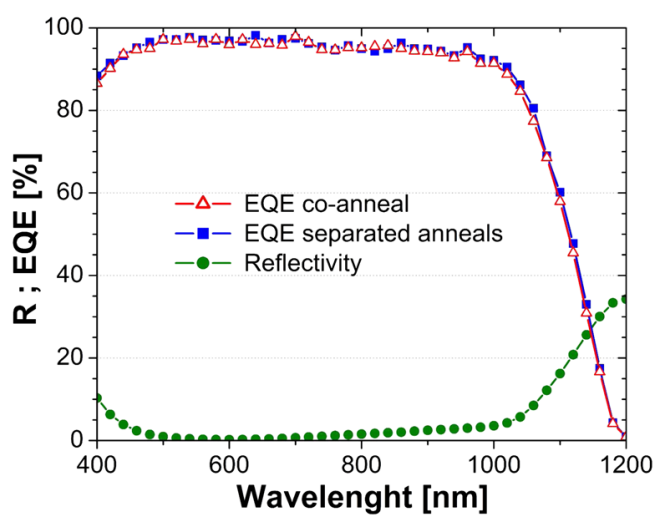

Figure 11. Reflectivity and EQE results of each process. 
Table III. $\mathrm{R}_{\mathrm{S}}, \mathrm{R}_{\text {shunt }}, \rho_{\text {contact BSF, }}$ PFF and $\mathrm{J}_{02}$ of implanted n-type PERT cells.

\begin{tabular}{lccccc}
\hline Cell type & $\begin{array}{c}R_{S} \\
{\left[\Omega . \mathrm{cm}^{2}\right]}\end{array}$ & $\begin{array}{c}\rho_{\text {contact BSF }} \\
{\left[\mathrm{m} \Omega . \mathrm{cm}^{2}\right]}\end{array}$ & $\begin{array}{c}P F F \\
{[\%]}\end{array}$ & $\begin{array}{c}R_{\text {shunt }} \\
{\left[\mathrm{k} \Omega . \mathrm{cm}^{2}\right]}\end{array}$ & $\begin{array}{c}J_{02} \\
{\left[\mathrm{nA} / \mathrm{cm}^{2}\right]}\end{array}$ \\
\hline $\begin{array}{l}\text { Separated } \\
\text { anneals }\end{array}$ & 0.60 & 4.8 & 83.5 & 170 & 2.3 \\
Co-anneal & 0.75 & 17.8 & 81.9 & 140 & 19.0 \\
\hline
\end{tabular}

Table IV. Variation of the different parameters after the laser edge isolation of the solar cells.

\begin{tabular}{llllllll}
\hline & $\begin{array}{l}\Delta V_{o c} \\
\text { Cell type }\end{array}$ & $\Delta J_{s c}$ & $\Delta F F$ & $\Delta \eta$ & $\Delta R_{s}$ & $\Delta P F F$ & $\Delta J_{o 2}$ \\
\hline $\begin{array}{l}\text { Separated } \\
\text { anneals }\end{array}$ & -0.7 & +0.2 & $+0.4+0.2$ & -0.17 & -0.1 & +1.8 \\
Co-anneal & -0.6 & +0.2 & $+0.6+0.2$ & -0.21 & +0.0 & +1.0 \\
\hline
\end{tabular}

The impact of the edges of the solar cell on the PFF and $\mathrm{J}_{02}$ values was studied by measuring the solar cells performances before and after the isolation of the edge by laser irradiation (cf. Table IV). For the two processes, even if a small increase of the FF is measured after the laser edge isolation, no variations were observed in the PFF values. The FF increase was only due to a decrease of the series resistance. The absence of improvement of the $\mathrm{J}_{02}$ values after the edge isolation show that the high $\mathrm{J}_{02}$ measured on the "co-anneal" process in Table III isn't related to shunt effect that could have occurred at the edge of the cell.

To conclude, the high $\mathrm{J}_{02}$ value seems to be due to stronger impact of contaminations induced by screenprinting paste on the less concentrated $\mathrm{BSF}_{\mathrm{A}}$ compared to the $\mathrm{BSF}_{\mathrm{B}}$. This explanation was supported by the higher drop of $\mathrm{V}_{\mathrm{oc}}$ measured after metallization in the "co-anneal" process.

Finally further optimizations on the screen-printing step were performed, leading to the reduction of the front metal shading from $6.6 \%$ to $6.1 \%$ thanks to narrower finger

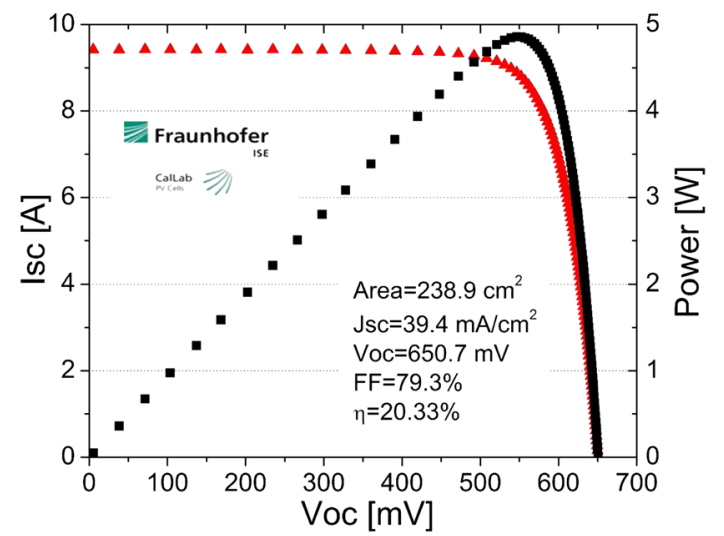

Figure 12. I(V) curves of the separated anneal solar cell certified by F. ISE CalLab at $20.33 \%$. widths. Following this optimization, the high efficiency potential of the "separated anneals" solar cells was confirmed by the certification of one of the solar cells by the Fraunhofer ISE CalLab. The solar cells efficiency was measured at $20.3 \%$ as shown on Figure 12.

\section{CONCLUSION}

One of the simplest processes for the fabrication of bifacial n-type PERT solar cells is based on a single high temperature annealing ("co-anneal"), to activate at the same time the implanted boron emitter and implanted phosphorus $\mathrm{BSF}$, and the use of this annealing to grow the $\mathrm{SiO}_{2}$ passivation layer. Considering implantation doses compatible with low contact resistances by usual screen-printing metallization pastes, it has been demonstrated that only the highest investigated thermal treatment with a peak temperature of $1050{ }^{\circ} \mathrm{C}$ offers a low emitter current saturation density $\mathrm{J}_{0 \mathrm{e}}$. The use of this high temperature for the P$\mathrm{BSF}$ anneal was beneficial in terms of implied $\mathrm{V}_{\mathrm{oc}}$ potential due a more suitable BSF profile for improved passivation.

Despite the loss in $\mathrm{J}_{0 \mathrm{e}}$ due to the use of the $\mathrm{SiO}_{2}$ passivation rather than a conventional $\mathrm{Al}_{2} \mathrm{O}_{3}$ layer, Implied $\mathrm{V}_{\mathrm{oc}}$ above $670 \mathrm{mV}$ were reached during solar cells fabrication. An average efficiency of $19.7 \%$ was obtained by our simple "co-anneal" process. The solar cells were mainly limited by a low PFF which seems to be reduced by a contamination effect of the rear screen-printing paste. This issue could be solved in the case of the "separated anneals" process flow where the P-BSF is annealed at lower temperature. In this case, a more concentrated and shallower PBSF profile is obtained, leading to lower $\mathrm{J}_{02}$ and higher FF. This second process yielded an average efficiency of $20.2 \%$ on a 15 cells batch with only one added step as compared to the "co-anneal" case.

One prospect to further optimize the "co-anneal" process remains the reduction of the global thermal budget of this annealing in order to solve the weakly concentrated P-BSF issue. However this optimization should go along with a decrease of the boron implantation dose in order to keep a low $\mathrm{J}_{0 \mathrm{e}}$ value.

\section{REFERENCES}

1. Kopecek R, Libal J. The status and future of industrial n-type silicon solar cells. Photovoltaics International 2013; 21st edn: 1-7

2. Bothe K, Schmidt J. Electronically activated boronoxygen-related recombination centers in crystalline silicon. Journal of Applied Physics 2006; 99(1): 013701.

3. Sopori B, Basnyat P, Devayajanam S, Shet S, Mehta V, Binns J, Appel J. Understanding light-induced degradation of c-Si solar cells. 38th IEEE Photovoltaic Specialists Conference 2012; 1115-1120. 
4. Macdonald D, Geerligs LJ. Recombination activity of interstitial iron and other transition metal point defects in p- and n-type crystalline silicon. Applied Physics Letters 2004; 85(18): 4061-4063.

5. Veschetti Y, Cabal R, Brand P, Sanzone V, Raymond G, Bettinelli A. High Efficiency on Boron Emitter nType $\mathrm{Cz}$ Silicon Solar Cells With Industrial Process. IEEE Journal of Photovoltaics 2011; 1(2): 118-122.

6. Bazer-Bachi B, Oliver C, Semmache B, Pellegrin Y, Gauthier M, Le Quang N, Lemiti M. Co-diffusion from boron doped oxide and POCl3. Proceeding of the 26th European Photovoltaic Solar Energy Conference and Exhibition, Hamburg, Germany 2011; 1155-1159.

7. Sheoran M, Emsley M, Yuan M, Ramappa D, Sullivan P. Ion-implant doped large-area N-type Czochralski high-efficiency industrial solar cells. 38th IEEE Photovoltaic Specialists Conference 2012; 2254-2257.

8. Spitzer MB, Tobin SP, Keavney CJ. High-efficiency ion-implanted silicon solar cells. IEEE Transactions on Electron Devices 1984; ED-31(5): 546-550.

9. Rohatgi A, Meier DL, McPherson B, Ok YW, Upadhyaya AD, Lai JH, Zimbardi F. High-throughput ion-implantation for low-cost high-efficiency silicon solar cells. Energy Procedia 2012; 15: 10-19.

10. Hieslmair H, Mandrell L, Latchford I, Chun M, Sullivan J, Adibi B. High throughput ion-implantation for silicon solar cells. Energy Procedia 2011; 27: 122-128.

11. Chunduri SK. Simply implants. Photon International, October 2013; 48-53.

12. Müller R, Benick J, Bateman N, Schön J, Reichel C, Richter A, Hermle M, Glunz SW. Evaluation of implantation annealing for highly-doped selective boron emitters suitable for screen-printed contacts. Solar Energy Materials and Solar Cells 2014; 120: 431-435.
13. Boscke TS, Kania D, Schollhorn C, Stichtenoth D, Helbig A, Sadler P, Braun M, Dupke M, Weis M, Grohe A, Lossen J, Krokoszinski HJ. Fully ion implanted and coactivated industrial n-type cells with 20.5\% efficiency. IEEE Journal of Photovoltaics 2013; 4: 48-51.

14. Gall S, Lanterne A, Manuel S, Sanzone V, Cabal R, Veschetti Y, Bettinelli A, Robin H, Lefillastre P, Gillot C. High efficient Industrial n-type Technology: From cell to module" Proceeding of the 28th EU PVSEC, Paris, France 2013.

15. Tao Y, Ok YW, Zimbardi F, Upadhyaya AD, Lai JH, Ning S, Upadhyaya VD, Rohatgi A. Fully ion-implanted and screen-printed $20.2 \%$ efficient front junction silicon cells on $239 \mathrm{~cm} 2$ n-type CZ substrate. IEEE Journal of Photovoltaics 2014; 4: 58-63.

16. Sinton RA, Cuevas A, Stuckings M. Quasi-steadystate photoconductance, a new method for solar cell material and device characterization. 25th IEEE Photovoltaic Specialists Conference 1996; 457-460.

17. Masetti G, Severi M, Solmi S. Modeling of carrier mobility against carrier concentration in arsenic-, phosphorus-, and boron-doped silicon. IEEE Transactions on Electron Devices 1983; 30(17): 764-769.

18. Lanterne A, Gall S, Manuel S, Monna R, Ramappa D, Yuan M, Rivalin P, Tauzin A. Annealing, passivation and contacting of ion implanted phosphorus emitter solar cells. Energy Procedia 2012; 27: 580-585.

19. Berger HH. Models for contacts to planar devices. Solid-State Electronics 1972; 15(4): 145-158.

20. Pysch D, Mette A, Glunz SW. A review and comparison of different methods to determine the series resistance of solar cells. Solar Energy Materials and Solar Cells 2007; 91: 1698-1706. 